\title{
PENGARUH DEBT COVENANT, BONUS PLAN, DAN POLITICAL COST TERHADAP KONSERVATISME AKUNTANSI
}

\author{
Okto Reyhansyah Iskandar, \\ Sparta* \\ STIE Indonesia Banking School \\ *) sparta@ibs.ac.id
}

\begin{abstract}
This research aims to understand and analyzes the effect of debt covenant, bonus plan, and political cost against company's accounting conservatism. Independent variable for which used in this research was debt covenant measured by the ratio of leverage, bonus plan measured by company share ownership by managers, and political cost measured by the size of the company. While the dependent variable measured by accounting conservatism. The sample selection is using purposive sampling method, in order to obtain 36 observations of manufacturing company which narrowed to subsector industrial consumer goods and consistently listed at Indonesia Stock Exchange during the period 2012-2015. This research uses secondary data from company financial statements obtained from the Indonesia Stock Exchange. Multiple linear regression technique is used in this research to achieve analytical results. The result showed that debt covenant have negative insignificant effects to accounting conservatism, bonus plan have negative and significant effects to accounting conservatism, and political cost it has positive effects and significantl to accounting conservatism.
\end{abstract}

Keywords: Accounting Conservatism, Debt Covenant, Bonus Plan, Political Cost

\section{PENDAHULUAN}

Sudah menjadi kewajiban bagi setiap perusahaan untuk menerbitkan laporan keuangan. Tujuan pelaporan keungan sudah tentu memiliki arti menyediakan informasi bagi para pemangku kepentingan di lingkaran perusahaan tersebut. Pentingnya informasi yang disediakan oleh perusahaan bersumber dari seluruh kegiatan operasional perusahaan namun, dalam hal ini manajemen tidak memberikan informasi secara begitu saja, laporan keuangan harus memenuhi tujuan, aturan serta prinsip-prinsip akuntansi yang sesuai dengan Standar Akuntansi Keuangan (SAK) dan setiap pelaporan keuangan akan melalui tahapan akuntansi. Yaitu: kegiatan transaki ekonomi, pencatatan transaksi, klasifikasi jenis transaksi, dan pelaporan (Financial Accounting, Weygandt, Kimmel, Kieso, 2012). Tahap pelaporan keuangan merupakan tahap akhir dari mengolah data hingga menjadi informasi yang bersifat siap pakai. Adapun informasi tersebut berpengaruh pada keputusan yang akan diambil oleh pengguna informasi dalam hal ini stakeholder. Keputusan stakeholder di pengaruhi dari informasi yang tersedia yaitu; informasi posisi keuangan suatu perushaan sehingga dapat menilai kinerja perushaan selama beberapa periode.

Tujuan dari laporan keungan yang sesuai dengan prinsip serta aturan yang ada dimaksudkan untuk menghasilkan laporan keuangan yang dapat dipertanggungjawabkan dan berguna bagi setiap pengguna laporan keuangan tersebut (Rahmawati, 2010). Standar Akuntansi Keuangan (SAK) memberikan kebebasan kepada setiap perusahaan dalam memilih metode akuntansi yang digunakan dalam menyusun laporan keuangan. Kebebasan manajemen dalam memilih metode akuntansi, dapat dimanfaatkan untuk menghasilkan laporan keuangan yang berbeda-beda di setiap perusahaan sesuai dengan keinginan dan kebutuhan perusahaan tersebut atau dengan kata lain perusahaan memiliki kebebasan dalam memilih salah satu dari beberapa alternatif yang ditawarkan dalam standar akuntansi keuangan yang dianggap sesuai dengan kondisi perusahaan. Pilihan metode tersebut akan 
berpengaruh terhadap angka yang disajikan dalam laporan keuangan, sehingga dapat dikatakan bahwa secara tidak langsung konsep konservatisme akan mempengaruhi hasil laporan keuangan.

Perusahaan memilih metode akuntansi yang dianggap sesuai dengan kondisi perusahaan dan yang dapat mengantisipasi kondisi perekonomian yang tidak stabil, artinya perusahaan berhati-hati dalam penyusunan laporan keuangan. Tindakan kehati-hatian yang dilakukan oleh perusahaan ini disebut sebagai konservatisme akuntansi. Implikasi konsep konservatisme terhadap prinsip akuntansi yaitu akuntansi mengakui biaya atau rugi yang kemungkinan akan terjadi, tetapi tidak segera mengakui pendapatan atau laba yang akan datang walaupun kemungkinan terjadinya besar. Basu (1997) menginterpretasikan konservatisme sebagai kecenderungan akuntan menggunakan tingkat verifikasi yang lebih tinggi untuk mengakui good news sebagai keuntungan dibanding mengakui bad news sebagai kerugian. Konservatisme akuntansi adalah prinsip yang menilai aset bersih yang terlalu rendah secara konsisten. Watts (2003) menyatakan bahwa understatement aset bersih yang sistematik atau relatif permanen merupakan konservatisme akuntansi, sehingga dapat dikatakan bahwa konservatisme akuntansi menghasilkan laba yang berkualitas karena prinsip ini mencegah perusahaan melakukan tindakan membesar-besarkan laba dan membantu pengguna laporan keuangan dengan menyajikan laba dan aset yang tidak overstatement. Konsekuensinya, apabila terdapat kondisi yang memiliki kemungkinan menimbulkan kerugian, maka biaya atau hutang tersebut harus segera diakui. Di sisi lain, apabila terdapat kondisi yang memiliki kemungkinan menghasilkan laba, maka pendapatan atau aset tersebut tidak boleh langsung diakui, sampai kondisi tersebut betul-betul telah terealisasi (Chariri dan Ghozali, 2007). Terdapat banyak kritikan yang muncul dari para peneliti, namun ada beberapa peneliti yang mendukung penerapan konservatisme akuntansi. Penerapan konservatisme akuntansi ini mengakibatkan laporan keuangan menjadi bias sehingga tidak dapat dijadikan sebagai alat untuk mengevaluasi terjadinya risiko suatu perusahaan (Haniati dan Fitriany, 2010).

Pihak yang kontra menilai laporan keuangan yang disusun berdasarkan metode yang konservatif akan cenderung bias karena tidak mencerminkan kondisi perusahaan yang sesungguhnya. Hal tersebut memunculkan keraguan tentang manfaat dari laporan keuangan yang disusun berdasarkan akuntansi yang konsevatif (Kiryanto dan Supriyanto, 2006). Konservatisme digunakan bila berhubungan dengan ketidakpastian dalam lingkungan dan kemungkinan optimisme berlebihan dari manajer dan pemilik (Belkoui, 2004). Motif pemilihan suatu metode akuntansi tidak terlepas dari Positive Accounting Theory (Watts dan Zimmerman, 1986). Penerapan konservatisme akuntansi ini perlu dipertimbangkan karena adanya fleksibilitas manajemen dalam menyajikan laporan keuangan dan mengingat beberapa kasus yang menyajikan laporan keuangan yang cenderung overstate yang berakibat menyesatkan pengguna laporan keuangan. Beberapa contoh kasus kecurangan manajemen dengan penyajian yang overstate adalah kasus kebangkrutan Enron Coorporation di Amerika Serikat dan jika mengambil contoh di dalam negeri kita dapat berkaca pada kasus kecurangan yang dilakuan oleh PT. Kimia Farma yang pernah menggelembungkan laba bersih senilai Rp 32,668 milyar. Tentunya hal ini menjadi kabar buruk dan merugikan bagi investor, kreditor dan pihak - pihak yang berkepentingan lainnya (Rahmawati, 2010).

Terlepas dari pro dan kontra mengenai penerapan akuntansi tersebut, penerapan konservatisme dalam akuntansi mengalami perkembangan beberapa dekade ini (Givoly and Hayn, 2000). Pada masa sekarang ini, konservatisme akuntansi lebih dikatakan sebagai prinsip kehati-hatian atau prudence. Akan tetapi, penerapan prudence tidak se-radikal konservatisme. Prinsip ini dapat mengakui adanya kenaikan aset atau menurunnya kewajiban dan beban dengan suatu kondisi tertentu walaupun belum terealisasi asalkan telah memenuhi kriteria pengakuan suatu pos. Hal ini dikarenakan dalam prudence, 
pendapatan juga dapat diakui sesegera mungkin ketika syarat pengakuan pendapatan sudah terpenuhi (Accounting Theory, Godfrey, 2010). Oleh karena itu penjelasan mengenai konservatisme ini menjadi menarik untuk dibahas karena berhubungan dengan pertimbangan-pertimbangan perusahaan dalam menerapkan akuntansi yang konservatif. Berdasar uraian di atas maka melalui artikel ini penulis akan mencoba memberikan penjelasan tentang beberapa faktor yang berpengaruh terhadap penerapan akuntansi konservatif perusahaan. Pertanyaan mendasar dalam penjelasan mengenai konservatisme ini adalah faktor-faktor apa sajakah yang mempengaruhi perusahaan dalam memilih prinsip akuntansi yang cenderung konservatif. Penulis melakukan review beberapa penelitian yang berhubungan dengan konservatisme akuntansi untuk mengetahui faktor apa sajakah yang mempengaruhi konservatisme akuntansi. Beberapa peneliti terdahulu telah meneliti mengenai faktor-faktor yang mempengaruhi akuntansi konservatif. Diantaranya hasil penelitian Anna (2010) yang menyatakan tidak adanya hubungan antara political cost dengan konservatisme akuntansi. Hasil ini berbeda dengan hasil penilitian yang dilakukan Alfiah (2011), dinyatakan adanya political cost sebagai faktor yang mempengaruhi konservatisme akuntansi atau dengan kata lain variabel independen political cost mempengaruhi variabel dependen yang menyebabkan hubungan positif. Sementara itu pnelitian Alexis (2013) membuktikan dengan debt covevnant sebagai variabel independen tidak berpengaruh terhadap konservatisme akuntansi namun hasil ini berbeda dengan penelitian yang dilakukan Valeri V. Nikolaev (2009), dinyatakan bahwa debt covenant berpengaruh positif terhadap konservatisme akuntansi. Penelitian lain Michael Raith (2009) dengan variabel independen bonus plan berpengaruh postif terhadap konservatisme akuntansi.

Atas dasar tidak konsistennya hasil temuan beberapa peneliti sebelumnya, maka peneliti termotivasi untuk melakukan uji pengaruh variabel debt covenant, bonus plan, dan political cost. Penelitian ini merupakan replikasi dari penilitian terdahulu dengan oleh Calvin (2012).

\section{TINJAUAN PUSTAKA DAN PENGEMBANGAN HIPOTESIS}

\subsection{Tinjauan Pustaka}

\section{Teori Agensi}

Penelitian ini dilandasi oleh teori agensi. Teori ini memegang peran penting dalam praktik bisnis perusahaan. Teori agensi merupakan teori yang muncul karena adanya konflik kepentingan antara prinsipal dan agen. Prinsipal sebagai pemilik sedangkan agen sebagai manajer. Prinsipal mengontrak agen untuk melakukan pengelolaan sumber daya dalam perusahaan. Tujuan utama dari teori keagenan adalah untuk menjelaskan bagaimana pihakpihak yang melakukan hubungan kontrak dapat mendesain kontrak yang tujuannya untuk meminimalisir cost sebagai dampak adanya informasi yang tidak simetris. Konsep Teori Agensi menurut Jensen dan Meckling (1976), mendefinisikan teori agensi itu sebagai hubungan keagenan sebagai suatu kontrak yang mana satu atau lebih principal (pemilik) menggunakan orang lain atau agent (manajer) untuk menjalankan aktifitas perusahaan. Prinsipal menyediakan fasilitas dan dana untuk kebutuhan operasi perusahaan, sedangkan agen sebagai pengelola berkewajiban untuk mengelola perusahaan sebagaimana dipercayakan oleh pemegang saham (principal), untuk meningkatkan nilai perusahaan.

Dalam praktiknya di perusahaan ternyata agen dalam aktifitasnya kadangkala tidak sesuai dengan kontrak kerja yang disepakati dari awal untuk meningkatkan kemakmuran pemegang saham melainkan cenderung untuk kepentingan sendiri, sehingga munculah suatu konflik keagenan. Dalam agency theory ini terjadi ketidakseimbangan informasi atau dengan kata lain asimetri informasi. Agen memiliki informasi yang lebih banyak dibandingkan dengan principal, sehingga menimbulkan adanya asimetri informasi yaitu suatu kondisi 
adanya ketidakseimbangan perolehan informasi antara pihak manajemen sebagai penyedia informasi dengan pihak pemegang saham dan stakeholder sebagai pengguna informasi. Pemilihan metode konservatisme tidak terlepas dari kepentingan manajer untuk mengoptimalkan keuntungan dengan mengorbankan kepentingan pemegang saham, sehingga dukungan manajemen terhadap konservatisme berkaitan dengan teori ini.

\section{Teori Akuntansi Positif}

Teori akuntansi positif seringkali berkaitan dengan konservatisme akuntansi karena menjelaskan faktor-faktor yang mempengaruhi dalam memilih prosedur akuntansi yang sesuai. Atas dasar tujuannya, teori akuntansi dapat dibedakan menjadi dua jenis, yaitu teori akuntansi normatif yang memberikan formula terhadap praktik akuntansi dan teori akuntansi positif yang berusaha menjelaskan dan memprediksi fenomena yang berkaitan dengan akuntansi dikutip dari Ghozali dan Anis, (2007) dalam Setijaningsih (2012). Teori akuntansi positif berusaha untuk mengidentifikasi proses dan kebijakan akuntansi yang paling sesuai untuk menghadapi kondisi dan keadaan tertentu pada masa yang akan datang. Perkembangan teori akuntansi positif ini muncul akibat ketidakpuasan terhadap teori akuntansi normatif, dasar pemikiran yang digunakan untuk menganalisis teori akuntansi pada teori normatif dianggap terlalu sederhana dan karena berdasar pada premis atau asumsi, bukan berdasarkan bukti empiris seperti halnya teori positif.

Menurut Watts dan Zimerman (1986) terdapat tiga hipotesis yang dikembangkan yaitu, hipotesis mengenai bonus plan, leverage, dan ukuran perusahaan. Hipotesis bonus plan menjelaskan tentang manager perusahaan(agent) yang cenderung menerapkan prosedur akuntansi dengan merubah pendapatan yang dilaporkan dimasa yang akan datang ke masa sekarang, atau dengan kata lain menaikan pencatatan pendapatan perusahaan, selain tidak ingin kinerja nya dinilai buruk, tujuan lain manager melakukan ini jelas karena termotivasi akan imbalan atau bonus yang tinggi terlebih lagi bila bonus yang didapat diukur dari pendapatan perusahaan. Berikutnya, manager berusaha untuk menekan biaya kontrak hutang tujuan nya adalah agar memudahkan disaat perusahaan membutuhkan pinjaman dana dari kreditur.

Watts dan Zimmerman (1986) menyatakan bahwa perusahaan besar akan dihadapkan pada biaya politik yang besar pulatermasuk menanggung beban pajak yang semakin besar, sehingga untuk menghindari hal tersebut, perusahaan yang besar relatif semakin konservatif untuk melaporkan pendapatan bersih yang semakin rendah akibat dari penundaan pengakuan laba dan mempercepat pengakuan kerugian. Hal ini ini berdampak pada biaya politik yang ditanggung oleh perusahaan akan semakin kecil (Watts dan Zimmerman, 1986) dalam Invin (2015).

\section{Debt Covenant}

Debt covenant adalah kontrak hutang yang ditujukan pada peminjam oleh kreditur dengan tujuan untuk mendapatkan pinjaman dana yang disertai perjanjian-perjanjian yang telah disepakati dalam pengembalian pinjaman tersebut. Sebagian kesepakatan hutang berisi perjanjian (covenant) yang mengharuskan peminjam memenuhi syarat yang disepakati dalam perjanjian hutang (Scott, 2000). Watts dan Zimerman (1986) mengidentifikasikan perjanjian seperti pembatasan dividen dan pembatasan pembelian kembali saham, pembatasan modal kerja, pembatasan merger, pembatasan akuisisi, pembatasan investasi, pembatasan pelepasan asset, pembatasan pembiayaan masa depan merupakan bentuk debt covenant.

Kontrak hutang jangka panjang (debt covenant) merupakan perjanjian untuk melindungi pemberi pinjaman (lender atau kreditor) dari tindakan-tindakan manajer terhadap kepentingan kreditur, seperti dividen yang berlebihan, pinjaman tambahan, atau 
membiarkan model kerja dan kekayaan pemilik berada di bawah tingkat yang telah ditentukan, yang mana semuanya menurunkan keamanan (atau menaikkan resiko) bagi kreditur yang telah ada. Kontrak ini didasarkan pada teori akuntansi positif, yakni hipotesis debt covenant, yang menyatakan bahwa semakin dekat suatu perusahaan ke pelanggaran perjanjian hutang, manajer memiliki kecenderungan untuk memilih prosedur akuntansi yang dapat memindahkan laba periode mendatang ke periode berjalan. Terkait dengan renegosiasi kontrak hutang, debt covenant cenderung untuk berpedoman pada angka akuntansi. Debt covenant memprediksi bahwa manajer cenderung untuk menyatakan secara berlebihan laba dan aset untuk mengurangi renegosiasi biaya kontrak hutang. Manajer juga tidak ingin kinerjanya dinilai kurang baik apabila laba yang dilaporkan konservatif. Leverage atau rasio utang adalah rasio total hutang terhadap total aset, dalam penelitian ini digunakan rasio debt to total asset ratio

\section{Bonus Plan}

Merupakan sebuah hipotesis dimana suatu prediksi yang membuat manager perusahaan lebih memilih prosedur akuntansi dengan merubah pendapatan yang dilaporkan untuk periode yang akan datang menjadi periode tahun berjalan (Godfrey, 2010). Wibowo (2002) menyatakan terdapat hubungan positif antara struktur kepemilikan manajerial dengan konservatisme akuntansi. Wardhani (2008) menyatakan bahwa kepemilikan saham oleh pihak manajemen akan menurunkan permasalahan agensi karena semakin banyak saham yang dimiliki oleh manajemen, maka semakin kuat motivasi mereka untuk bekerja dalam meningkatkan nilai saham perusahaan. Selain jika ada bonus plan yang disepakati, maka manajer akan cenderung kurang konservatif karena dengan meningkatkan laba manajer akan dinilai memiliki kinerja yang bagus dan dapat mencapai target sehingga bonus yang diberikan banyak

\section{Political Cost}

Bagi perusahaan, intensitas politik sering berkaitan dengan ukuran perusahaan (Watts and Zimmerman, 1986) perspektif tersebut mengembangkan pemahaman (Godfrey, 2010), mentransfer kekayaan atau dana dari sebuah perusahaan dikarenakan terpapar keadaan politiknya. jumlah yang di transfer sering kali berkaitan dengan ukuran dan yang tampak pada perusahaan. (Godfrey, 2010). Political cost mengungkapkan bahwa perusahaan besar kemungkinan menghadapi biaya politis lebih besar dibanding perusahaan kecil. Perusahaan besar biasanya lebih diawasi oleh pemerintah dan masyarakat. Jika perusahaan besar mempunyai laba yang tinggi secara relatif permanen, maka pemerintah dapat terdorong untuk menaikkan pajak dan meminta layanan publik yang lebih tinggi kepada perusahaan. Akhirnya, manajer perusahaan besar mungkin cenderung memilih metode akuntansi yang menunda pelaporan laba untuk mengurangi tanggungan political cost oleh perusahaan.

\subsection{Pengembangan Hipotesis}

Debt covenant atau kontrak hutang yang diproksikan dengan rasio leverage berupa debt-to-total asset ratio menggambarkan kemampuan perusahaan dalam membayar kewajiban nya dari setiap total asset yang dimiliki. Kontrak hutang dapat mengindikasikan bahwa manajer cenderung menyatakan laba dan asset secara berlebihan untuk mengurangi renegosiasi biaya kontrak hutang. Sari dan Adhariani (2009) menyatakan bahwa semakin tinggi rasio leverage, semakin besar pula kemungkinan perusahaan akan menggunakan prosedur yang meningkatkan laba yang dilaporkan. Calvin (2012) menyatakan debt covenant berpengaruh negatif terhadap konservatisme akuntansi. Namun, hasil berbeda diperoleh Resti (2012), dimana penelitian tersebut menemukan kontrak hutang berpengaruh signifikan terhadap konservatisme akuntansi. Mengacu pada tinjauan pustaka dan penelitian terdahulu di atas, maka dapat dirumuskan pengembangan hipottesa pertama, yaitu ; 
$\mathrm{H}_{1}$ : Debt covenant berpengaruh negatif terhadap konservatisme akuntansi

Bonus plan menyatakan bahwa manajer dari perusahaan yang memiliki kebijakan bonus akan cenderung memilih prosedur yang mengalihkan laba dari periode mendatang ke periode berjalan (Watts dan Zimmerman 1986). Dalam hipotesis ini dikatakan bahwa bonus atau kompensasi menjadi salah satu alasan yang mendorong manajer untuk melaporkan laba yang diperolehnya secara optimis dalam suatu periode Calvin (2012). Hal ini disebabkan karena bonus yang diterima oleh manajer biasanya berkaitan dengan kinerja yang dicapai oleh manajer, yang tersaji di dalam laba pada laporan laba rugi. Semakin tinggi laba yang dicapai, maka semakin tinggi pula kompensasi yang akan diterima.

Dalam penelitian Wardhani (2008) dan Brilitanti (2013) menyatakan bahwa bonus plan yang di proksikan dengan saham yang dimiliki pihak manajerial memiliki pengaruh negatif terhadap konservatisme akuntansi hal ini dikarenakan manajer semakin bertindak tidak knservatif mengingat jumlah bonus yang diperoleh berdasar dari laba yang dihasilkan perusahaan otomatis muncul hubungan negatif antara variabel ini dengan konservatisme akuntansi itu sendiri. Mengacu pada tinjauan pustaka dan penelitian-penelitian terdahulu di atas, maka dirumuskan pengembangan hipotesi kedua sebagai berikut :

$\mathrm{H}_{2}$ : Bonus plan berpengaruh negatif terhadap konservatisme akuntansi

Biaya politis muncul akibat kepentingan antara perusahaan dengan pemerintah. Hal ini menyebabkan pihak perusahaan menjadi rentan akan konflik yang mungkin muncul akibat pertentangan antara regulasi pemerintah dengan aksi yang dilakukan oleh perusahaan. Selain itu grup tertentu juga memiliki keinginan untuk melakukan lobby terhadap pemerintah dalam hal nasionalisasi, pengambil alihan suatu objek, perpecahan, atau aturan perusahaan yang makin memperkuat kemungkinan munculnya regulasi yang dapat merugikan perusahaan (Watts dan Zimmerman, 1978). Watts dan Zimmerman (1986) juga menyatakan bahwa manajer ingin mengecilkan laba dengan tujuan untuk mengecilkan biaya politis yang ditanggung oleh perusahaan. Hal ini akan mengakibatkan manajer cenderung memilih prosedur dan metode akuntansi yang melaporkan laba lebih rendah atau konservatif. Dalam hipotesis ini juga dikatakan bahwa besarnya biaya politis sangat tergantung dari ukuran perusahaan (Watts dan Zimmerman, 1978). Oleh karena itu dapat disimpulkan bahwa perusahaan besar lebih sensitif daripada perusahaan kecil karena terkait dengan biaya politis dan oleh karenanya perusahaan tersebut menghadapi kecenderungan yang berbeda dalam pemilihan prosedur metode akuntansi. Tujuan dilakukannya pemilihan prosedur akuntansi tersebut adalah untuk meminimalkan laba, sehingga mengurangi biaya politis yang mungkin dapat terjadi.

Dalam penelitian Angga dan arifin (2013) dan Calvin (2012) menyatakan bahwa political cost terbukti tidak berpengaruh terhadap konservatisme akuntansi. Dengan laba yang tinggi maka pemerintah dapat terdorong untuk menaikkan pajak dan meminta layanan publik yang lebih tinggi kepada perusahaan. Akhirnya, manajer perusahaan besar mungkin cenderung memilih metode akuntansi yang menunda pelaporan laba untuk mengurangi tanggungan political cost oleh perusahaan Calvi (2012).

Mengacu pada tinjauan pustaka dan penelitian-penelitian terdahulu di atas, maka dirumuskan pengembangan hipotesi ketiga sebagai berikut :

$\mathrm{H}_{3}$ : Political cost berpengaruh positif terhadap konservatisme akuntansi.

\subsection{Kerangka Pemikiran}

Penelitian ini menggunakan variabel dependen yaitu konservatisme akuntansi. Variabel independen yang digunakan dalam penelitian ini adalah debt covenant yang diproksikan dengan rasio leverage berupa debt-to-total asset ratio, bonus plan yang 
diproksikan dengan rasio saham yang dimiliki manajerial, dan political cost yang diproksikan dengan logarithma natural dari total asset. Pada penelitian ini, peneliti menguji tentang pengaruh debt covenant, bonus plan dan political cost secara parsial terhadap konservatisme akuntansi. Berdasarkan uraian diatas, model penelitian ini dapat digambarkan dalam bentuk kerangka pemikiran sebagai berikut :

Variabel Independen

\section{Gambar 1. Rerangka Pemikiran}

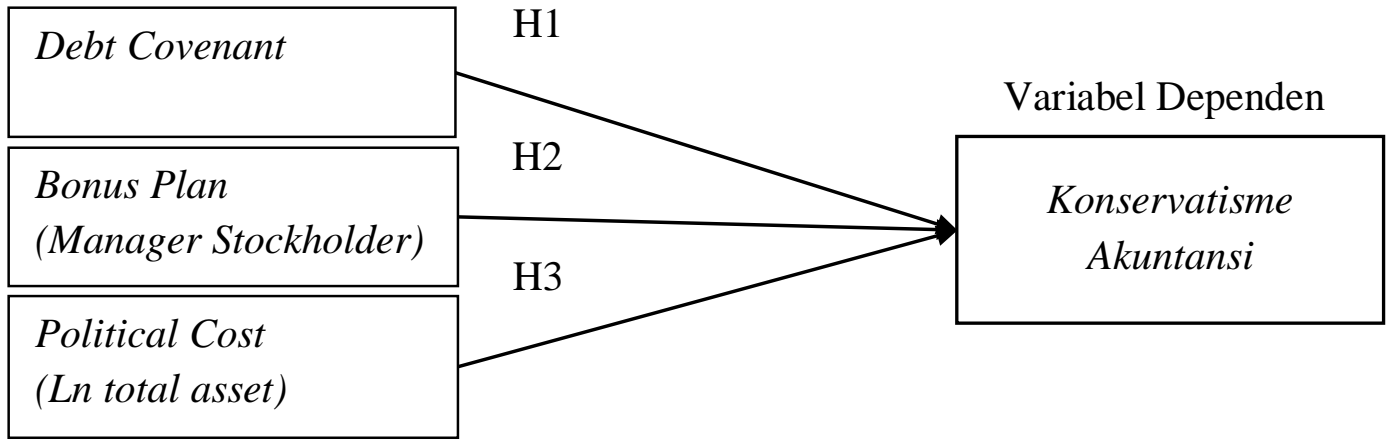

Sumber: Data diolah penulis

\section{METODE PENELITIAN}

Penelitian ini menggunakan sampel perusahaan manufaktur sub sektor barang konsumsi yang terdaftar di Bursa Efek Indonesia (BEI) periode 2012-2015 yang dipilih dengan metode purposive sampling. Berdasarkan kriteria yang telah ditetapkan pada bab III, diperoleh jumlah sampel sebanyak 9 perusahaan yang terdaftar di Bursa Efek Indonesia (BEI) periode 2012-2015 dengan data observasi sebanyak 36.

Variabel dependen yang digunakan dalam penelitian ini adalah Konservatisme Akuntansi. Seperti penelitian Givoly dan Hayn (2002) konservatisme diukur dengan model yang dikembangkan menggunakan conditional conservatism, persamaannya adalah sebagai berikut :

$$
\begin{aligned}
& C_{-} C O N_{i t}=T O T_{-} A C C_{i t}-O P_{-} A C C_{i t} \\
& \text { TOT }_{A C C_{i t}}=N I_{i t}+\text { Depre }_{i t}-C F O_{i t} \\
& O P_{\_} A C C_{i t}=\Delta A / R_{i t}-\Delta I n v_{i t}-\Delta P_{r e \_} \exp _{i t}+\Delta A / P_{i t}+\Delta T a x \_p y b_{i t}
\end{aligned}
$$

Variabel independen yang digunakan dalam penelitian ini terbagi menjadi tiga, yaitu debt covenant, bonus plan, dan political cost. Debt covenant yang di proksikan dengan rasio leverage dengan menggunakan Return to Total Asset Ratio, dengan rumus :

$$
\text { Debt To Total Asset }\left(L E V_{i t}\right): \frac{\text { Total Liabilities }}{\text { Total Assets }}
$$

Bonus plan yang dihitung dengan jumlah kepemilikan saham oleh manager, dengan rumus :

$$
\text { Saham Kepemilikan Manajerial (COMP it) : } \frac{\text { Jumlah Saham Milik Manajer }}{\text { Jumlah Saham Beredar }}
$$

Political Cost diproksikan dengan ukuran perusahaan yang dengan Ln Total Aset.

Analisis data yang menggunakan analisis regresi berganda ini menggunakan model yaitu :

Keterangan:

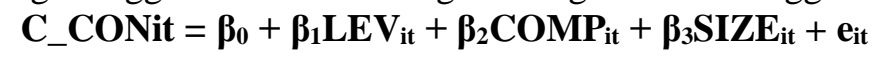

$$
\begin{array}{ll}
\text { C_CON }_{\text {it }} & \text { : Pengukuran conditional conservatism. } \\
\boldsymbol{\beta}_{\mathbf{0}} & : \text { Konstanta } \\
\beta_{1}-\beta_{3} & : \text { Koefisien Regresi }
\end{array}
$$



$\mathrm{LEV}_{\text {it }}$
: Debt covenant yang diproksikan dengan rasio leverage perusahaan i pada tahun $\mathrm{t}$.
COMP it $_{\text {it }} \quad$ Bonus plan yang diproksikan dengan struktur kepemilikan manajerial i pada tahun $\mathrm{t}$.
SIZE $_{\text {it }} \quad:$ Political cost yang diproksikan dengan ukuran perusahaan.
i : Time series identifiers
$\mathrm{t} \quad$ : Cross section identifiers

\section{HASIL DAN PEMBAHASAN \\ 4.1. Statistik Deskriptif}

Tabel 1. Statistik Deskripti Variabel Penelitian

\begin{tabular}{lcccc}
\hline & C_CONit & LEV $_{\text {it }}$ & $\begin{array}{c}\text { BONUS } \\
\text { PLAN }\end{array}$ & $\begin{array}{c}\text { POLITICAL } \\
\text { COST }\end{array}$ \\
\hline Mean & $1.95^{\mathrm{E}+11}$ & 0.391273 & 0.035354 & 25.13666 \\
Median & $9.70^{\mathrm{E}+10}$ & 0.395658 & 0.001387 & 27.14581 \\
Maximum & $9.18^{\mathrm{E}+11}$ & 0.639053 & 0.230769 & 28.80543 \\
Minimum & $-4.44^{\mathrm{E}+09}$ & 0.130592 & $2.25^{\mathrm{E}-05}$ & 17.54143 \\
Std. Dev. & $2.29^{\mathrm{E}+11}$ & 0.129770 & 0.079442 & 4.009124 \\
Skewness & 1.406109 & -0.047943 & 2.062709 & -1.130441 \\
Kurtosis & 4.487498 & 2.228552 & 5.301243 & 2.558250 \\
Observations & 36 & 36 & 36 & 36 \\
\hline \multicolumn{2}{l}{ Sumber: Data sekunder yang diolah, 2016 }
\end{tabular}

Berdasarkan hasil pengolahan data pada gambar 2 di bawah, didapatkan nilai Jarque-Bera sebesar 0.957927 yang berarti nilai tersebut kurang dari 2, sehingga dapat disimpulkan bahwa data dalam penelitian ini terdistribusi normal. Untuk lebih memperkuat asumsi atas normalitas data dalam penelitian ini, selanjutnya dilakukan analisis terhadap nilai probabilitas yang diketahui yang diketahuui nilanya sebesar 0.619425 yang menunjukan bahwa nilai ini lebih besar dari $5 \%$, dengan kata lain $\mathrm{H}_{\mathrm{o}}$ diterima yang berarti residual data terdistribusi normal dengan jumlah observasi sebanyak 36.

Gambar 2. Uji Normalitas Persamaan Regresi

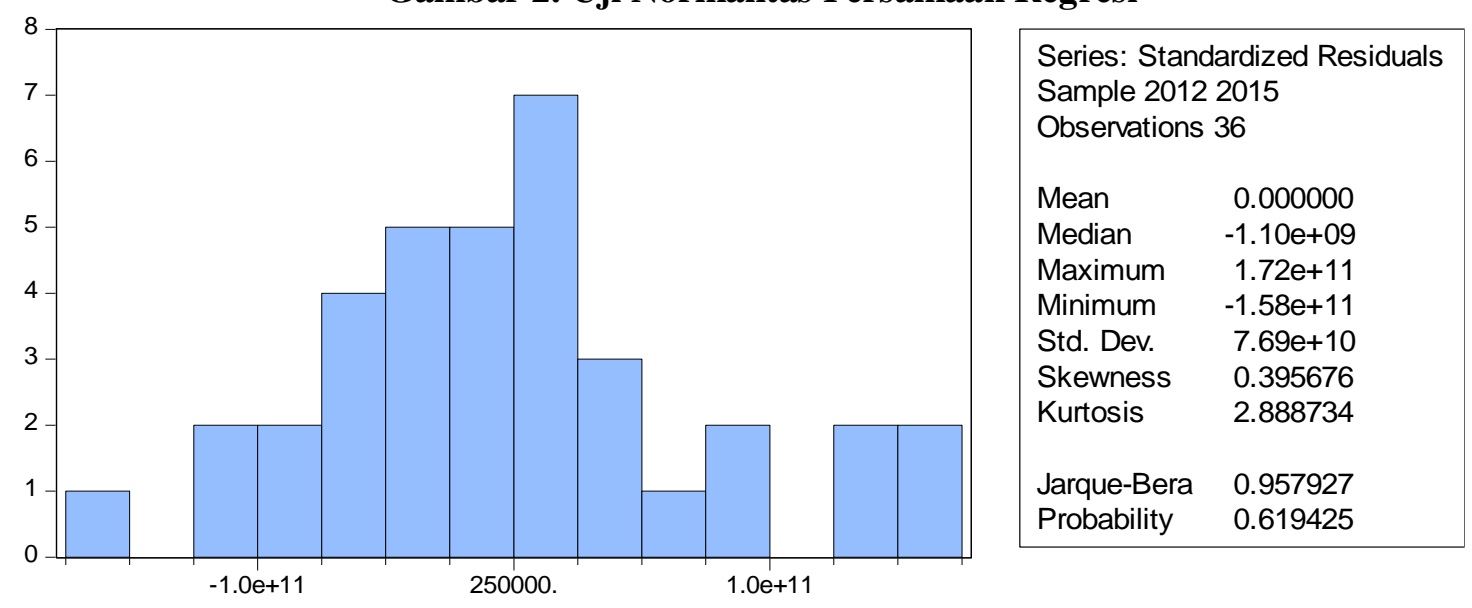

Sumber : data diolah penulis

Tabel 2. Hasil Uji Chow

EQUITY: Jurnal Ekonomi, Manajemen, Akuntansi | Vol. 22, No. 1 


\begin{tabular}{lccc}
\hline Effects Test & Statistic & d.f. & Prob. \\
\hline Cross-section F & 11.115100 & $(8,24)$ & 0.0000 \\
Cross-section Chi-square & 55.750782 & 8 & 0.0000 \\
\hline
\end{tabular}

Sumber: Data sekunder yang diolah, 2016

Hasil uji chow pada tabel 2 di atas, menujukkan nilai probabilitas cross section chi square adalah 0. Nilai tersebut lebih rendah dari nilai probabilitas chi square 0,05. Dengan demikian, $\mathrm{H}_{\mathrm{a}}$ dinyatakan diterima sehingga dapat dikatakan bahwa hasil regresi model dalam penelitian ini menggunakan model fixed effect dan dapat dilanjutkan ke uji Hausman.

Tabel 3. Hasil Uji Hausman

\begin{tabular}{lccc}
\hline Test Summary & Chi-Sq. Statistic & Chi-Sq. d.f. & Prob. \\
\hline Cross-section random & 15.811565 & 3 & 0.0012 \\
\hline
\end{tabular}

Sumber: Data sekunder yang diolah, 2016

Hasil uji Hausman pada tabel 3 di atas, dapat diketahui nilai probabilitas cross section random adalah sebesar 0,0012 . Nilai tersebut lebih rendah dari nilai probabilitas cross section random sebesar 0,05. Dengan demikian $\mathrm{H}_{\mathrm{a}}$ dinyatakan diterima sehingga dapat dikatakan bahwa hasil regresi model dalam penelitian ini menggunakan model fixed effect.

Uji multikolinearitas bertujuan untuk menguji apakah dalam model regresi ditemukan adanya korelasi antar variabel bebas (Winarno, 2011). Model regresi yang baik seharusnya tidak terjadi korelasi antar Uji multikolinearitas dapat dilakukan dengan melakukan analisa correlation matrix untuk mengetahui hubungan antara dua atau lebih variabel independen secara bersama sama mempengaruhi satu variabel independen lain variabel bebasnya. Hasil perhitungan nilai correlation matrix dapat diketahui pada tabel 4 di bawah ini :

Tabel 4. Hasil Uji Multikolinearitas Coefficients

\begin{tabular}{cccc}
\hline & LEV & BONUS PLAN & POLITICAL \\
COST
\end{tabular}

Sumber: Data sekunder yang diolah sendiri.

Berdasarkan hasil pengolahan data yang telah dilakukan pada tabel 4 di atas bahwa nilai korelasi antar variabel tidak ada yang melebihi diatas nilai 0,85 , sehingga dapat disimpulkan bahwa dalam penelitian ini tidak ditemukan adanya multikolinearitas antar variabel independen.

Uji heterokedastisitas dalam penelitian ini dilakukan dengan menggunakan Uji Park. Uji Park dilakukan dengan menggunakan cara meregresikan nilai residual dengan masingmasing variabel independen (Ghozali, 2009). Hipotesis yang dibuat dalam uji heterokedatisitas ini adalah Ho: Tidak ada gejala heterokedastisitas dan Ha: Ada gejala heterokedastisitas. Pengambilan keputusan dalam pengujian ini adalah : Jika probability (signifikansi) $\geq \alpha \quad 0,05$ maka $\mathrm{H}_{0}$ diterima, Jika probability (signifikansi) $<\alpha 0,05$ maka $\mathrm{H}_{0}$ ditolak. Hasil uji heterokedastisitas dengan menggunakan Uji Park diperlihatkan di tabel dibawah ini : 
Tabel 5. Hasil Uji Park (Heterokedastisitas)

\begin{tabular}{cccl}
\hline Variable & Coefficient & t-Statistic & Prob. \\
\hline LEV & $-1.32 \mathrm{E}+22$ & -1.208907 & 0.2356 \\
BONUS PLAN & $-1.78 \mathrm{E}+22$ & -1.014866 & 0.3178 \\
POLITICAL COST & $-1.50 \mathrm{E}+20$ & -0.432941 & 0.6680 \\
\hline
\end{tabular}

Pada tabel 5 di atas, dapat dilihat bahwa hasil regresi nilai residual dengan masingmasing variabel independen memiliki tingkat signifikansi diatas 0,05 atau 5\%. Hal ini dapat disimpulkan bahwa model regresi pada penelitian ini bebas dari masalah heterokedastisitas, dengan kata lain hipotesis Ho dalam penelitian ini diterima dan Ha ditolak.

Uji autokorelasi bertujuan untuk melihat hubungan antara residual satu observasi dengan residual observasi lainnya. Sehingga, pengujian ini dilakukan untuk mengidentifikasi adanya hubungan antara residual observasi dengan observasi lainnya (Gujarati, 2010). Dalam penelitian ini uji autokorelasi dilakukan melalui pengujian terhadap nilai DurbinWatson. Hasil uji autokorelasi pada penelitian ini dapat dilihat pada tabel 6 dibawah. Hasil uji autokorelasi pada tabel 5 menunjukan bahwa nilai Durbin-Watson stat sebesar 2.459788 artinya nilai $D W$ berada pada kondisi $1.54<2.459788<2,46$ yang menunjukan bahwa tidak ditemukan adanya masalah autokorelasi pada model persamaan regresi.

Uji statistik t dilakukan untuk menguji hipotesis 1, 2 dan 3, dengan mengetahui apakah koefisien regresi dari variabel indeoenden secara individual atau parsial berpengaruh secara signifikan terhadap variabel dependen. Berikut hasil uji statistik dari penelitian ini dapat dilihat pada tabel 6 di bawah ini.

Tabel 6. Hasil Uji Hipotesis Statistik t

\begin{tabular}{crrr}
\hline \multicolumn{1}{c}{ Variable } & Coefficient & t-Statistic & \multicolumn{1}{c}{ Prob. } \\
\hline LEV & $-4.41^{\mathrm{E}+11}$ & -1.230656 & 0.2387 \\
BONUS PLAN & $-2.98^{\mathrm{E}+15}$ & -5.959385 & 0.0000 \\
POLITICAL COST & $7.16^{\mathrm{E}+11}$ & 6.808584 & 0.0000 \\
C & $7.09^{\mathrm{E}+13}$ & 4.633471 & 0.0004 \\
AR (1) & $7.24^{\mathrm{E}-5}$ & 6.642504 & 0.0000 \\
\hline R-squared & 0.982462 & & \\
Adjusted R-squared & 0.967430 & & \\
F-statistic & 65.35706 & & \\
Prob(F-statistic) & 0.000000 & & \\
Durbin-Watson stat & 2.459788 & & \\
\hline Surb & & & \\
\hline
\end{tabular}

Sumber: Data sekunder yang diolah

\subsection{Analisis Hasil Penelitian}

Berdasarkan hasil penelitian yang dilakukan, menunjukan bahwa pada periode 20122015 debt covenant yang di proksikan dengan leverage dan dihitung dengan debt to total asset ratio menunjukan pengaruh negatif tidak signifikan terhadap konservatisme akuntansi pada perusahaan sampel. Kemungkinan variabel debt covenant bukan salah satu faktor yang menentukan tinggi atau rendahnya konservatisme akuntansi pada suatu perusahaan. Leverage bukan satu-satunya perhitungan yang dapat dijadikan variabel dalam suatu penelitian untuk mengukur konservatisme. Karena sampel pada penelitian ini merupakan perusahaan manufaktur, dimana nilai aset perusahaan menyumbang pengaruh relatif besar pada total aset dalam memperhitungkan debt to total asset ratio sehingga perhitungan perlu disesuaikan dengan perusahaan selain manufaktur. Hasil penelitian ini tidak sesuai dengan teori yang di ungkapkan oleh Valeri V. Nikolaev (2009) bahwa debt covenant dapat 
mempengaruhi konservatisme akuntansi suatu perusahaan apabila diukur dengan ketepatan pengakuan kerugian.

Di sisi lain, penelitian ini tidak mendukung penelitian Dinny Prastiwi Brilianti (2013) yang menyatakan bahwa tidak adanya pengaruh antara leverage dengan konservatisme akuntansi, karena perusahaan tidak membutuhkan leverage untuk menerapkan konservatisme.

Berdasarkan hasil penelitian yang dilakukan, menunjukan bahwa pada periode 20122015, bonus plan yang di proksikan dengan kepemilikan manajerial pada perusahaan menunjukan pengaruh negatif signifikan terhadap konservatisme akuntansi pada perusahaan sampel penelitian.

Penelitian ini mendukung temuan Ratna Whardani (2008) bahwa kepemilikan manajerial berpengaruh negatif terhadap konservatisme perusahaan. Hal ini disebabkan bahwa bonus plan ynag diharapkan oleh manajer dinilai dari perolehan laba perushaan apabila laba perusahaan dinilai menurun maka semakin kecil pula perolehan bonus yang terima dari pemilik perushaan(principal).

Berdasarkan hasil penelitian yang dilakukan, menunjukan bahwa pada periode 20122015, political cost menunjukan pengaruh positif signifikan terhadap konservatisme akuntansi pada perusahaaan sampel penelitian. Hasil dalam penelitian ini mendukung penelitian Angga dan Arifin (2013), yang membuktikan bahwa political cost yang positif, dapat mempengaruhi konservatisme akuntansi perusahaan. Pihak otoritas dalam hal ini pemerintah melakukan pengawasan terhadap setiap perusahaan yang melakukan kegiatan produksi, biaya yang timbul dikarenakan pemerintah sudah menetapkan biaya yang harus di tanggung perusahaan terkait dampak yang timbul dari kegiatan operasional perusahaan. Di sisi lain kegiatan politik suatu negara dapat memberi sentimen akan perubahan suatu kebijkan, baik dari sisi fiskal maupun kebijakan perdagangan. Hal inilah yang membuat suatu perusahaan mempertimbangkan untuk menerapkan kebijakan akuntansi yang konservatisme dalam kegiatan bisnisnya.

\section{SIMPULAN, KETERBATASAN DAN SARAN}

\subsection{Simpulan}

Debt covenant berpengaruh negatif terhadap konservatisme akuntansi, semakin rendah nilai debt covenant perusahaan maka tingkat konservatifnya semakin meningkat. Bonus plan berpengaruh positif terhadap konservatisme akuntansi. Hal ini menunjukan bahwa variabel bonus plan bukan merupakan faktor yang mempengaruhi konservatisme akuntansi. Political cost berpengaruh positif terhadap konservatisme akuntansi, semakin tinggi nilai political cost maka tingkat konservatifnya semakin meningkat.

\subsection{Keterbatasan}

Keterbatasan penelitian ini adalah sebagai berikut 1). Penelitian hanya meniliti variabel bebas debt covenant, bonus plan dan political cost, penelitian selanjutnya diharapkan menambah variabel bebas lain yang mempengaruhi konservatisme akuntanssi seperti tingkat intensitas modal, kepemilikan publik, dan sebagainya. 2). Penelitian ini hanya menelitia dalam jumlah sampel terbatas yaitu 9 perusahan yang masuk dalam industri manufaktur selama empat tahun atau 36 observasi. Diharapkan pada penelitian berikutnya dapat menambah jumlah sampel, sehingga hasil yang diperoleh akan lebih valid.

\subsection{Saran}

Berdasarkan pemaparan diatas, dapat dikatakan bahwa debt covenant berpengaruh negatif tidak signifikan terhadap konservatisme akuntansi. Rasio total hutang terhadap total 
asset menunjukan ketergantungan perusahaan terhadap pihak ketiga dalam menjalankan kegiatan produksi perusahaan, walaupun setiap pinjaman yang dibuat dijaminkan akan terbayar oleh setiap rupiah dalam total aset. Namun bukan tidak mungkin langkah ini dapat menimbulkan risiko gagal bayar di masa yang akan datang. Hasil ini memiliki implikasi bahwa pengguna laporan keuangan harus memahami betul penerapan konservatisme akuntansi pada suatu perusahaan. Penelitian ini memberi bukti bahwa perusahaan dengan tingkat kontrak hutang (debt covenant) yang tinggi bisa berdampak pada penerapan konservatisme akuntansi yang relatif rendah. Hal ini wajar dapat dilakukan oleh setiap perusahaan untuk memperoleh kreditur dengan mudah.

Menurut hasil regresi mengenai pengaruh bonus plan terhadap konservatisme akuntansi, menunjukan bahwa bonus plan memiliki pengaruh negatif dan signifikan terhadap konservatisme akuntansi. Pengaruh ini menjelaskan bahwa semakin tinggi bonus plan suatu perusahaan maka tingkat konservatisme akuntansi perusahaan tersebut relatif semakin rendah. Penelitian ini memberi gambaran pada investor jika ingin berinvestasi dapat mempertimbangkan jumlah kepemilikan saham yang dimiliki oleh manajer untuk menilai tangkat konservatisme akuntansi perusahaan tersebut. Tingkat konservatif merupakan faktor penting dalam mengambil suatu keputusan yang berkaitan dengan keputusan bisnis, karena perusahaan yang konservatif cenderung berhati-hati dalam menentukan dan suatu keputusan.

Menurut hasil regresi mengenai pengaruh political cost terhadap konservatisme akuntansi menunjukan bahwa political cost memiliki pengaruh positif signifikan terhadap konservatisme akuntansi. Pengaruh ini menjelaskan bahwa semakin tinggi ukuran suatu perusahaan, makan semakin tinggi pula penerapan konservatisme akuntansinya. Penelitian ini membuktikan bahwa manajer akan mencoba sebisa mungkin untuk meminimalkan biaya politik. Pada dasarnya biaya politik muncul karena adanya aturan-aturan yang di buat oleh pihak otoritas, aturan yang dibuat terkadang berbenturan dengan kegiatan bisnis perusahaan. Sehingga perusahaan harus dibebankan dengan biaya yang telah ditetapkan. Pandangan lain mengenai political cost, adalah biaya politis timbul akibat adanya sentimen dari kegiatan politik pada suatu negara. Hasil ini memberi implikasi bahwa pengguna laporan keuangan dapat menilai tingkat konservatisme akuntansi yang diterapkan perusahaan dengan melihat ukuran perusahaan. Pandangan ini dapat memutuskan bahwa perusahaan yang besar tentunya memiliki nilai konservatisme yang tinggi untuk menghindar dari terpaparnya biaya politik dibanding perusahaan yang kecil.

Hasil penelitian ini dapat dijadikan bahan pertimbangan pengguna laporan keuangan dalam mengevaluasi pentingnya penerapan konservatisme akuntansi suatu perusahaan, baik menilai dari sisi investasi maupun menilai keberlanjutan bisnis suatu perusahaan.

\section{DAFTAR PUSTAKA}

Ahmed, A. S. (2000). 'Accounting Conservatism And Cost Of Debt : An Emprical Test Of Efficient Contracting”. Vol.36, Maret 2000.

Ahmed, A. S., \& Duellman, S. (2012). "Managerial Overconvidence and Accounting Conservatism. Journal of Accounting Research”, Vol. 51(1), 46. Julin2012. Retrieved from http://mays.tamu.edu/

Alfian, A., \& Sabeni, A. (2013). "Analisis Faktor-Faktor Yang Berpengaruh Terhadap Pemilihan konservatisme Akuntansi”. Diponegoro Journal Of Accounting, Vol. 2(No. 3), 1-10. Retrieved from http://ejournal-s1.undip.ac.id/index.php/accounting 
Anthony, R. N., Hawkins, D. F., \& Merchant, K. A. (2007). Accounting : Text And Case. 12th International Edition ed. Singapore: Mc Graw Hill.

Ashton, D. J., \& Wang, P. (2010). “Conservatism And The Ohlson Model” Vol.. 38.Juni,2010

Astika, R. M. (2009,). "Pengaruh Konservatisme Akuntansi Terhadap Persistensi Laba Pada Industri Manufaktur Yang Terdaftar Di Bursa Efek". 99. Juli 24

Balakhrisnan, K., Watts, R. L., \& Zuo, L. (2016,). "The Effect Of Accounting Conservatism On Corporate Investment During Global Financial Crisis”. Journal Of Business Fianance And Accounting, Vol.45. Mei 26

Belkoui, A. (2004). Accounting Theory, 5th ed.. U.S.A: Thomson South Western.

Biddle, G. C. (2015, Juli). Accounting Conservatism and Bankruptcy Risk. 57.

Cooper, D. R., \& Schindler, P. S. (2011). Business Reaserch Methods, 1th International Edition ed.,. Singapore: Mc Graw Hill.

Dai, L., \& Ngo, P. (2015,). "Political Uncertainty And Accounting Conservatism”. 47. Oktober 25

Dinanar Hati, L. A. (2011,). “Telaah Literatur Tentang Faktor-Faktor Yang Mempengaruhi Konservatisme Akuntansi”. Jurnal Ekonomi \& Pendidikan, Vol. 8(No. 2). November

Ekananda, M. (2014). Analisis Ekonometrika Data Panel. Jakarta: Mitra Wacana Media.

Financial Accounting Standard Boards. (2008). Statements Of Financial Accounting Concepts No. 2. Retrieved from Financial Accounting Standard Boards: http://www.fasb.org/jsp/FASB/Document_C/DocumentPage?cid=1218220132599\&acc eptedDisclaimer=true

Garcia, J. M., Osma, B. G., \& Penalva, F. (2016). Accounting Conservatism And Firm Investment Efficiency. Journal Of Accounting And Economics, Vol. 61(1), 47.

Ghazali, I., Anis, \& Chariri. (2007). Teori Akuntansi. Badan Penerbit Universitas Diponegoro.

Ghozali, I. (2005). Aplikasi Analisis Multivariate dengan program SPSS. Semarang: Badan Peneribit Univesitas Dipenogoro.

Givoly, D., Hayn, C., \& Natarajan, A. (2004, Oktober). Measuring Reporting Conservatism. 49.

Godfrey, J., Hodgson, A., Targa, A., Hamilton, J., \& Holmes, S. (2010). Accounting Theory (7th ed.). Milton, Queensland, Australia: John Wiley \& Sons Australia, Ltd.

Gujarati, D. (2007). Dasar - Dasar Ekonometrika Jilid 1. Jakarta: Penerbit Erlangga.

Haniati, S., \& Fitriany. (2010). Pengaruh Konservatisme Terhadap Asimetri Informasi. Simposium Nasional Akuntansi 2013, 28.

EQUITY: Jurnal Ekonomi, Manajemen, Akuntansi | Vol. 22, No. 1 159 DOI: 10.34209/equ.v22i1.896 
Ikatan Akuntan Indonesia. (2014). PSAK 53, Pembayaran Berbasis Saham. In I. A. Indonesia, Standar Akuntansi Keuangan. DSAK IAI.

Jensen, M. C., \& Meckling, W. H. (1976,). "Theory Of The Firm : Managerial Behavior, Agency Cost And Ownership Structure”. Journal Of Financial Economics, III, 305-360. Juli

Kurniawan, A. J. (2013,). "Faktor-Faktor Yang Mempengaruhi Konservatisme Akuntansi Pada Perusahaan Manufaktur”. 36. Agustus 21

LaFond, R., \& Roychowdhury, S. (2007,). "Managerial Ownership And Accounting Conservatism". 55. Februari

Lee, J. (2012,). “The Role Of Accounting Conservastism In Firms' Financial Decisions”. 45. November 23

Lee, T. (2014,). "Agency Costs Of Equity And Accounting Conservatism : A Real Options Approach”. 22. Februari 12

M. De Araujo, I. J. (2015). "Hubungan Simultan Antara Konservatisme Akuntansi Dan Kesulitan keuangan".

Mudrajad, K. (2003). Metode Riset Untuk Bisnis \& Ekonomi. Surabaya: Erlangga.

Nikolaev, V. V. (2009, Maret). "Debt Covenant And Accounting Conservatism". Journal of Accounting Research, Vol. 48,(1), 41.

Oktomegah, C. (2013,). "Faktor faktor Yang Mempengaruhi Penerapan Konservatisme Akuntansi Pada Perusahaan Manufaktur Di BEI”. Jurnal Ilmiah Mahasiswa Akuntansi, Vol. 1(No. 1). Januari

Rahmawati. (2010,). "Pengaruh Karakteristik Dewan Sebagai Salah Satu Mekanisme Corporate Governance Terhadap Konservatisme Akuntansi Di Indonesia”. Diponegoro University Institutional Repository. Oktober 13

Raith, M. (2009,). "An Agency theory Of Conservative Acrual Accounting”. Simon School Working Paper(FR 9-11), 37. Agustus 23

Ramalingegowda, S., \& Yu, y. (2011,). "Institutional Ownership And Conservatism”. Journal of Accounting And Economics, 47. Juni 27

Research, M. (2011, December 2). "pengambilan-keputusan-dengan-p-value" Jurnal Maxima. Retrieved from maximaresearch.wordpress.com: https://maximaresearch.wordpress.com/2011/12/02/pengambilan-keputusan-dengan-pvalue/

Resti. (2012). “Analisis Faktor-Faktor Yang Mempengaruhi konservatisme Akuntansi”. 99. 
Saputri, Y. D. (2013). "Faktor-faktor Yang Mempengaruhi Pilihan Perusahaan Terhadap konservatisme Akuntansi”. Accounting Analysis Journal, AAJ 2(2), 8.

Schroeder, R. G., Clark, M. W., \& Cathey, J. M. (2014). Financial Accounting Theory And Analysis : Text And Case, 11th ed.. US: John Wiley \& Sons Ltd.

Scott, W. R. (2011). Financial Accounting Theory,6th ed.. Toronto, Ontario, Canada: Pearson Canada Inc.

Sekaran, U., \& Bougie, R. (2013). Research Methods for Business, 6th ed.. United Kingdom: John Wiley \& Sons Ltd.

Setijaningsih, H. T. (2012). “Teori Akuntansi Positif Dan Konsekuensi Ekonomi”. Jurnal Akuntansi Volume XVI No. 3, 427-438.

Sudipta, B. (1997, Desember). "The Conservatism Principle And The Asymmetric Timeliness Of Earnings". Journal Of Accounting And Economics, Vol. 24(I), 3-37.

Syahrul, Y. (2002). Mark Up Kimia Farma Tanggung Jawab Direksi Lama. TEMPO News Room. Jakarta: TEMPO.

Umar, H. (2000). Research Methods in Finance and Banking. Jakarta: PT Gramedia Pustaka Utama.

Wang, R. Z., Zijl, T. V., \& Hogartaigh, C. Ó. (2008,). "Measures Of Accounting Conservatism : A Construct Validity Perspective". Journal Of Accounting Literature, 61. September 25

Wang, R. Z., Zijl, T. V., \& Hogartaigh, C. Ó. (2009,). “A Signaling Theory of Accounting”. 50. Juni 6

Wardhani, R. (2008,). "Tingkat Konservatisme Akuntansi Di Indonesia Dan Hubungannya Dengan Karakteristik Dewan Sebagai Salah Satu Mekanisme Corporate Governance”. Simposium Nasional Akuntansi, Vol. XI, 1-26. Januari

Watts, R. L. (2003,). “Conservatism In Accounting Part I : Explanations And Implication”. Simon School Of Business Woriking Paper(FR 3-16), 35. Mei 16

Watts, R. L. (2003,). "Conservatism In Accounting Part II : Evidence And Research Opportunities". Simon School Of Business Working Paper(FR 3-25), 36. Agustus 21

Watts, R. L., \& Zimmerman, J. L. (1990,). "Positive Accounting Theory". The Accounting Review, Vol. 65(No. 1), 131-156. Januari

Weygandt, J. J., Kimmel, P. D., \& Kieso, D. E. (2011). Financial Accounting IFRS Edition. United States of America: John Wiley \& Sons, Inc.

Widarjono, A. (2009). Ekonometrika Pengantar dan Aplikasinya Edisi 3. Yogyakarta: Ekonisia.

EQUITY: Jurnal Ekonomi, Manajemen, Akuntansi | Vol. 22, No. 1 | 61 DOI: 10.34209/equ.v22i1.896 
Widarjono, A. (2009). Ekonometrika Teori \& Aplikasi Untuk Ekonomi dan Bisnis. Jakarta: Fakultas Ekonomi UI.

Winarno, W. W. (2011). Analisis Ekonometrika dan Statistika dengan Eviews Edisi 3. Yogyakarta: Unit Penerbit dan Percetakan STIM YKPN Yogyakarta. 